\title{
PENGARUH MOTIVASI, KARAKTERISTIK PEKERJAAN, SERTA IKLIM ORGANISASI MENGENAI KEPUASAN KERJA PADA KARYAWAN HOTEL IBIS BUDGET DIPONEGORO SURABAYA
}

\author{
Friskha Rostinaningsih¹, Christina Menuk Srihandayani2, Bisma Arianto ${ }^{3}$ \\ Universitas PGRI Adi Buana Surabaya1, \\ friskharostina29@gmail.com
}

\begin{abstract}
ABSTRAK
Eksplorasi ini bertujuan untuk memahami asertaya efek secara simultan serta parsial antara Motivasi, Karakteristik Pekerjaan serta Iklim Organisasi mengenai Kepuasan Kerja pada Karyawan Hotel Ibis Budget Diponegoro Surabaya. Besaran responden yang diambil sebanyak 30 orang karyawan, serta menggunakan teknik purposive sampling. Data dikumpulkan melewati kuesioner dengan menggunakan skala likert, kemudian melewati tahap uji validitas, reliabilitas, uji asumsi klasik serta terakhir teknik analisis yang digunakan yaitu Regresi Linier Berganda. Nilai Hasil dari pengolahan data, menunjukkan bahwa adanya pengaruh secara simultan Motivasi, Karakteristik Pekerjaan serta Iklim Organisasi mengenai Kepuasan Kerja Karyawan. Sesertagkan uji hipotesis secara parsial pada variabel Motivasi, menunjukkan Motivasi tidak berdampak signifikan pada Kepuasan Kerja. Selanjutnya, Karakteristik Pekerjaan serta Iklim Organisasi berdampak signifikan secara parsial mengenai Kepuasan Kerja pada Karyawan Hotel Ibis Diponegoro Surabaya.
\end{abstract}

Kata kunci: Motivasi, Karakteristik Pekerjaan, Iklim Organisasi, Kepuasan Kerja

\begin{abstract}
This exploration aims to understand the simultaneous and partial effect of asertaya between motivation, occupational characteristics and organizational climate on job satisfaction at Ibis Budget Diponegoro Surabaya Hotel employees. The size of respondents taken by 30 employees, as well as using saturated sampling. Data is collected through questionnaires using Likert scales, then passing the validity test, reliability, classical assumption test and the last analytical technique used in double linear regression. The value of data processing results, indicating that there is a simultaneous influence of motivation, occupational characteristics and organizational climate on employee satisfaction. A partial hypothesis test is defined in the motivation variable, indicating motivation does not have a significant impact on job satisfaction. Furthermore, occupational characteristics and organizational climate have a partial impact on job satisfaction at the employees of Hotel Ibis Diponegoro Surabaya.
\end{abstract}

Keyword: Motivation, Job Characteristics, Organizational Climate, Job Satisfaction 


\section{PENDAHULUAN}

Surabaya menggambarkan salah satu kota dengan kemajuan dunia bisnis yang sangat laju serta bisa dikatakan sangat signifikan. Dikatakan demikian lantaran pembangunan infrastruktur yang berjalinan dengan sarana maupun prasarana sebagai penunjang perekonomian yang juga berkembang sangat signifikan. Pembangunan tersebut diantaranya, akses pendidikan, akses transportasi, banyaknya gedung yang bertingkat serta pelaku bisnis yang sangat banyak di Surabaya.

Pariwisata adalah kesibukan seseorang melanglang atau berdiam di suatu tempat untuk keriangan, bisnis maupun tujuan lainnya. Pariwisata saat ini yang tumbuh di Indonesia sangat berkembang dengan pesat. Surabaya dijuluki sebagai kota metropolitan. Surabaya juga dikenal sebagai salah satu tujuan wisata yang dikunjungi oleh pengunjung baik Lokal maupun dari Mancanegara.

Maka dari itu, pengusaha menggunakan peluang yang ada untuk membuka usaha seperti kuliner dengan makanan khas Surabaya serta juga menyediakan layanan jasa akomodasi penginapan (hotel). Menjamurnya industri jasa perhotelan di kota pahlawan ini, mengacu dengan bermunculnya berbagai hotel dalam macam-macam tipe serta ukuran. Definisi hotel, yaitu perusahaan yang ditata oleh pemilik dengan menyediakan akomodasi untuk beristirahat kepada para tamu yang mengadakan perjalanan serta sanggup membayar dengan besaran harga pelayanan yang diterima oleh para tamu.

Secara global, hotel berguna untuk menangani akomodasi bagi para tamu yang mencari tempat untuk beristirahat untuk sementara waktu. Fungsi lain dari hotel sangat bervariatif, menjadi tempat pertemuan rapat, seminar maupun acara tertentu. Keberhasilan hotel tidak hanya ditetapkan oleh pelayanan jasanya saja, tetapi oleh kualitas sumber daya manusianya yang profesional. Lantaran itu, dalam meningkatkan produktivitas karyawan yang maksimal serta profesional perlu ditingkatkan dalam berbagai macam aspek seperti berasal dari dalam diri karyawan contohnya motivasi, pelatihan karakteristik pekerjaan yang ada di hotel Ibis Budget Diponegoro Surabaya tersebut. Kemudian, terciptanya iklim organisasi yang baik bisa membuat karyawan bekerja efektif serta efisien. Dari ketiga ini, pasti akan berdampak kepada kepuasan karyawan saat mereka bertugas.

\section{RUMUSAN MASALAH}

Adapun rumusan masalah yang ingin dikaji yaitu :

1. Bagaimana Motivasi berdampak mengenai Kepuasan Kerja ?

2. Bagaimana Karakteristik Pekerjaan berdampak mengenai Kepuasan Kerja ?

3. Bagaimana Iklim Organisasi berdampak mengenai Kepuasan Kerja ?

4. Bagaimana Motivasi, Karakteristik Pekerjaan serta Iklim Organisasi berdampak secara simultan mengenai Kepuasan Kerja pada Karyawan Hotel Ibis Budget Diponegoro Surabaya?

\section{TINJAUAN PUSTAKA Motivasi}

Motivasi sangat diperlukan oleh semua karyawan. Dengan motivasi yang terdapat dalam diri karyawan, sangat merajai mereka dalam mengadakan pekerjaannya dengan begitu maksimal sehingga terciptanya bekerja dengan profesional serta mereka akan merasakan kepuasan kerja dalam diri masing-masing.

Ada dua faktor yang dapat memenuhi kepuasan kerja pegawai. Diantaranya, diukur melalui faktor Intrinsik serta faktor Ektrinsik. Yang pertama, faktor Intrinsik meliputi kebutuhan dalam berprestasi, serta juga kebutuhan dalam hal kepentingan. Yang kedua, faktor Ektrinsik yaitu kebutuhan rasa aman dalam bekerja, 
kebutuhan gaji maupun promosi serta jabatan. Motivasi bersifat jangka panjang. Lantaran itu karyawan terus menerus diberikan kepercayaan penuh untuk menyelesaikan tugasnya dengan baik.

\section{Karakteristik Pekerjaan}

Konsepsi perihal kerja serta pekerjaan yang dikemukakan oleh Malthis serta Jackson (2011) yakni upaya yang difokuskan untuk menggapai hasil yang maksimal. Pekerjaan adalah pembagian tugas serta tanggung jawab yang menggambarkan penempatan kerja mutlak bagi karyawan. Karakteristik pekerjaan yakni susunan pekerjaan yang dibuat meliputi keterampilan yang sesuai, identitas tugas pekerjaan serta umpan balik yang dicapai karyawan.

\section{Iklim Organisasi}

Iklim organisasi menggambarkan lingkungan internal dalam organisasi yang dialami setiap masingmasing anggota serta dapat menguasai setiap tingkah laku individu anggota.

\section{Kepuasan Kerja}

Kepuasan kerja dapat diartikan dengan penilaian karyawan mengenai hasil yang didapat dalam mereka bekerja. Semakin besar hasil atau timbal balik yang didapat, maka kepuasan kerja pada karyawan akan meningkat.

\section{KERANGKA KONSEPTUAL}

Bersumber pada teori diatas, maka kerangka yang dibuat seperti gambar berikut :

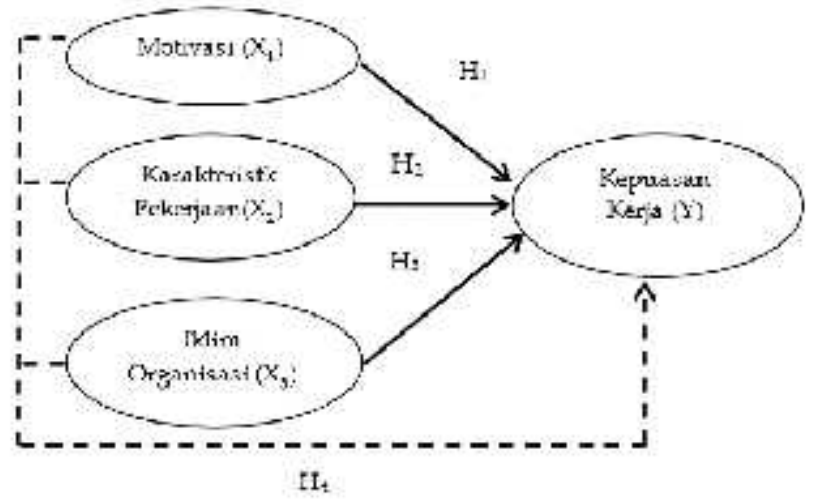

Gambar 1 Kerangka Konseptual Penelitian

\section{HIPOTESIS EKSPLORASI}

Setelah mengamati adanya keterkaitan variabel bersumber pada kerangka konseptual diatas, maka hipotesis dalam studi ini yaitu :

Diduga Motivasi, Karakteristik Pekerjaan serta Iklim Organisasi berdampak mengenai Kepuasan Kerja Pada Karyawan Hotel Ibis Diponegoro Surabaya.

\section{METODE}

\section{Populasi serta Sampel}

Populasi dalam eksplorasi ini yaitu karyawan Hotel Ibis Budget Diponegoro Surabaya yang berkuantitas 30 orang. Metode pengumpulan sampel memakai teknik purposive sampling dimana mengambil seluruh populasi dilantarankan kurang dari 100 orang. 


\section{Variabel serta Definisi Operasional Variabel}

a. Motivasi

Motivasi merealisasikan dukungan positif yang diperlukan masing-masing individu karyawan guna dapat melaksanakan pekerjaannya dengan penuh semangat serta profesional.

b. Karakteristik Pekerjaan

Karakteristik pekerjaan yakni susunan pekerjaan yang dibuat meliputi keterampilan yang sesuai, identitas tugas pekerjaan serta umpan balik yang dicapai karyawan.

c. Iklim Organisasi

Iklim Organisasi menggambarkan suatu kondisi lingkungan kerja yang menjadi ciri khas dari suatu organisasi perusahaan yang terbentuk meliputi perilaku maupun kepribadian dari keseluruhan anggota.

d. Kepuasan Kerja

Kepuasan kerja menggambarkan tingkat keriangan yang dirasakan oleh pribadi karyawan dimana mereka mendapatkan imbalan yang sesuai dengan pekerjaan mereka.

\section{Instrumen Eksplorasi, Uji Validitas, serta Uji Reliabilitas}

Dalam pengumpulan data pada riset ini, penulis menyebarkan kuesioner diantaranya terdiri dari variabel bebas $X$ meliputi $X_{1}$ (Motivasi) ; $X_{2}$ (Karakteristik Pekerjaan) ; $X_{3}$ (Iklim Organisasi) maupun variabel terikat $Y$ (Kepuasan Kerja).

Uji validitas dipakai untuk menguji bagaimana setiap butir pernyataan pada kuesioner mampu memperlihatkan dengan pasti apa yang akan diteliti. Kriteria dalam uji validitas ini, dikatakan valid jika nilai signifikan lebih kecil dari 5\% $(<0,05)$. Begitu juga sebaliknya, apabila nilai signifikan lebih besar dari 5\% $(>0,05)$ maka dinyatakan tidak valid.Untuk menguji reliabilitas pada instrumen yang telah dibuat menggunakan Alpha Cronbach(á). Jika hasil eksplorasi menunjukkan nilai (á) berada diatas 0,6, maka dapat dikatakan data eksplorasi ini reliabel.

\section{Analisis Data}

Setelah data diperoleh, berikutnya analisis Regresi Linier Berganda, dengan dibantu program SPSS versi 25. Pengetesan hipotesis menggunakan model sebagai berikut :

$$
Y=a+b_{1} X_{1}+b_{2} X_{2}+b_{3} X_{3}+e
$$

Keterangan :

$\mathrm{Y}=$ Variabel dependen (Kepuasan Kerja)

$\mathrm{a}=$ Konstanta

$b_{1}=$ Koefisien regresi Motivasi

$b_{2}=$ Koefisien regresi Karakteristik Pekerjaan.

$b_{3}=$ Koefisien regresi Iklim Organisasi.

$\mathrm{e}=$ Ero 


\section{HASIL}

Tabel 1 Hasil Uji Validitas

\begin{tabular}{|c|c|c|c|c|}
\hline \multirow[t]{8}{*}{ Furisbl } & & Cenralation & $B_{i f}$ & IStesnege: \\
\hline & $\approx .11$ & $07 \%$ & Doce & vald \\
\hline & $=7 z$ & RTS & IIIK? & i shat \\
\hline & $x: 1,3$ & 0,705 & Doce & ridid \\
\hline & $x .21$ & 0.11 & Dus, & lald \\
\hline & $y .12$ & 0,862 & 2000 & "idd \\
\hline & $\therefore 2,3$ & 0,200 & Dose & SNid \\
\hline & $x: 21$ & 0.000 & $D 000$ & vald \\
\hline \multirow[t]{12}{*}{ Matrisei(//) } & 3.3 .2 & OBS & $D 000$ & $\Leftrightarrow$ Iid \\
\hline & J.2. & $0,00 \%$ & Doc: & valid \\
\hline & $=4,1$ & Bas & IUEบ & $x$ ahd \\
\hline & $\because 44_{2}$ & 0,725 & $D 0 C O$ & rolid \\
\hline & X...4. & 0,725 & Doce & valld \\
\hline & $=4$ & BVA & IUKA & S shad \\
\hline & $x .5 .2$ & 0,010 & Doco & raid \\
\hline & $x=0$ & 0,72 & $D 000$ & videl \\
\hline & Y:S & R.AOO & nom & $v=l i d$ \\
\hline & $x 0.22$ & 0.522 & DOC1 & Vald \\
\hline & $x 221$ & 00000 & $D 000$ & vald \\
\hline & $=12-1$ & $B+4 y$ & Les? & $x=$ hid \\
\hline \multirow{12}{*}{ 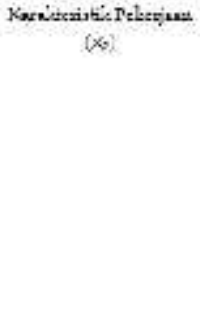 } & $\times 22,3$ & 0.55 & Doces & vid \\
\hline & 2022 & 0,227 & Dose & vald \\
\hline & $\approx 3,3$ & 0,855 & Doco & relid \\
\hline & $x_{2.11}$ & $0,5 \pi$ & Docs & rid \\
\hline & $x: 42$ & 0200 & Ju: & $x$ ald \\
\hline & $y=43$ & 0,500 & 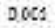 & rid \\
\hline & $\infty .1,1$ & 0.200 & $D O C=$ & vald \\
\hline & $\approx 0.12$ & 0,502 & Doces & vald \\
\hline & $y: 3.13$ & 0.542 & Doce & r.sid \\
\hline & $\$ \omega_{2,1}$ & 0,000 & Doce & raid \\
\hline & 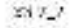 & Dind & HeVI & x alid \\
\hline & $y 323$ & 0,507 & 2000 & relid \\
\hline \multirow{9}{*}{$\begin{array}{c}\text { 1hline Cryanisast } \\
\text { Nal }_{2}\end{array}$} & $\$ 201$ & 0,005 & DOCO & visil \\
\hline & sary & inis & 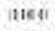 & tehd \\
\hline & $\times 3,3$ & 0,504 & Docs & rid \\
\hline & $20 . \pm 1$ & 0.51 & $D 0 C 1$ & Salid \\
\hline & $2 \times 4.2$ & 0.495 & nose & $V$ :lid \\
\hline & $\times 9.13$ & 0.580 & DoC: & ridid \\
\hline & 2031 & 0.05 & DOCO & vald \\
\hline & $\because y$ & R/AT & $10 \times 11$ & S alid \\
\hline & $\times 35,3$ & 0,567 & 0000 & rid \\
\hline
\end{tabular}

\section{Sumber : Data diolah}

Dari hasil uji validitas diatas, seluruh item yang diuji menunjukkan nilai signifikansi < 0,05 (5\%). Maka dari itu, seluruh variabel dapat digunakan untuk selanjutnya.

\section{Uji Reliabilitas}

Tabel 2 Hasil Uji Reliabilitas

\begin{tabular}{cccc}
\hline Variabel & Nilai Alpha Cronbach & Nilai Kritis & Keterangan \\
\hline Motivasi $\left(\mathrm{X}_{1}\right)$ & 0,900 & 0,6 & Reliabel \\
Karakteristik Pekerjaan $\left(\mathrm{X}_{2}\right)$ & 0,792 & 0,6 & Reliabel \\
Iklim Organisasi $\left(\mathrm{X}_{3}\right)$ & 0,860 & 0,6 & Reliabel \\
\hline
\end{tabular}

Sumber : Data diolah 
Dari hasil tabel diatas, bahwa instrumen pada masing-masing variabel dalam kuesioner, menunjukkan nilai Alpha Cronbach lebih besar dari nilai kritis yakni 0,6 serta dapat dikatakan bahwa pernyataan kuesioner tersebut reliabel.

\section{Uji Asumsi Klasik Uji Normalitas}

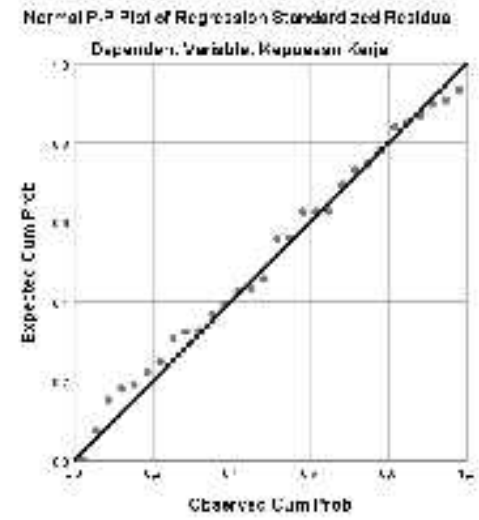

\section{Gambar 2 Scatterplot Uji Normalitas}

Dari gambar diatas, dikatakan bahwa data berdistribusi normal, lantaran titik-titik yang menyebar serta mendekati garis diagonal.

\section{Uji Multikolinieritas}

\begin{tabular}{lc}
\multicolumn{2}{c}{ Tabel 3 Nilai VIF } \\
\hline \multicolumn{1}{c}{ Model } & VIF \\
\hline Motivasi $\left(X_{1}\right)$ & 1,030 \\
Karakteristik Pekerjaan $\left(X_{2}\right)$ & 1,506 \\
Iklim Organisasi $\left(X_{3}\right)$ & 1,542 \\
\hline
\end{tabular}

Uji multikolinieritas dipakai pada model regresi untuk menguji terdapat jalinan atau korelasi pada variabel bebas. Dalam eksplorasi ini, hasil yang diperoleh nilai VIF pada variabel bebas kurang dari 10. Dapat dikatakan eksplorasi ini bebas dari multikolinieritas atau dengan kata lain tidak ada korelasi antar variabel bebas.

\section{Uji Autokorelasi}

\section{Tabel 4 Nilai Durbin Watson}

\begin{tabular}{cc}
\multicolumn{2}{c}{ Model Summary } \\
\hline Model & $\begin{array}{c}\text { Durbin } \\
\text { Watson }\end{array}$ \\
\hline 1 & 2,074 \\
\hline
\end{tabular}


Dari hasil pada tabel diatas dalam uji autokorelasi, diperoleh nilai Durbin Watson sekuantitas 2,074. Nilai Durbin Watson lebih besar dari batas bawah (dL) yaitu 1,213 serta kurang dari batas atas yakni 2,351. Maka bisa disebut bebas dari autokorelasi.

\section{Uji Heteroskedastisitas}

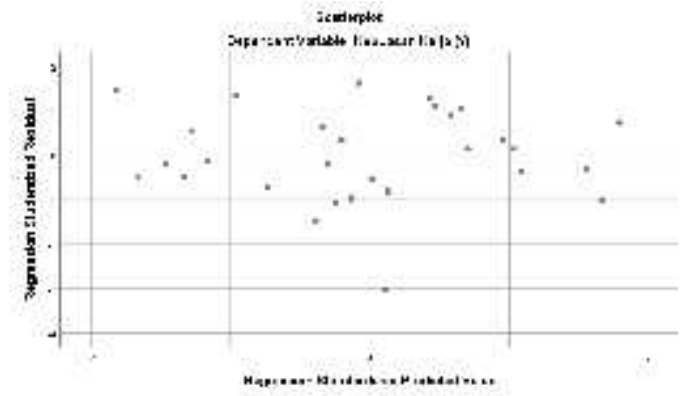

Gambar 3 Hasil Uji Heteroskedastisitas

Gambar diatas, dapat dilihat tidak membentuk pola yang jelas serta menyebar secara acak, maka dalam uji tersebut tidak terjadi heteroskedastisitas pada model regresi.

\section{Analisis Regresi Linier Berganda}

\begin{tabular}{|c|c|c|c|c|}
\hline \multirow{2}{*}{ Model } & \multicolumn{2}{|c|}{ Unstandardized Coefficient } & \multirow[b]{2}{*}{$t$} & \multirow[b]{2}{*}{ Sig. } \\
\hline & B & Std. Error & & \\
\hline (Constant) & 7,875 & 8,259 & 0,954 & 0,349 \\
\hline Motivasi $\left(X_{1}\right)$ & 0,010 & 0,061 & 0,164 & 0,871 \\
\hline Karakteristik Pekerjaan $\left(\mathrm{X}_{2}\right)$ & 0,352 & 0,133 & 2,639 & 0,014 \\
\hline Iklim Organisasi $\left(X_{3}\right)$ & 0,988 & 0,127 & 7,777 & 0,000 \\
\hline $\mathrm{R}=0,918$ & & & & \\
\hline R Square $=0,843$ & & & & \\
\hline F Sig $=0,000$ & & & & \\
\hline
\end{tabular}

Dari hasil yang ditunjukkan pada tabel diatas, diperoleh persamaan regresi liner berganda yaitu : $\mathrm{Y}=$ $7,875+0,010 x_{1}+0,352 x_{2}+0,988 x_{3}+0$

Dari persamaan regresi linier berganda diatas, terdapat nilai beta positif. Diantaranya, $(\beta 1=0,010 ; \beta 2$ $=0,352 ; \beta 3=0,988$ ). Dari nilai beta positif ini, bahwa variabel $X_{1}, X_{2}$ serta $X_{3}$ berdampak positif mengenai variabel $Y$.

Saat Motivasi, Karakteristik Pekerjaan serta Iklim Organisasi terjadi peningkatan, akan berdampak meningkatnya Kepuasan Kerja. Pada saat terbentuk peningkatan akan Motivasi sekuantitas satu satuan, maka Kepuasan Kerja akan bertambah 0,010 saat variabel yang lain tetap.

Selanjutnya, Kepuasan Kerja meningkat sekuantitas 0,352 pada saat Karakteristik Pekerjaan meningkat satu satuan dengan ketentuan variabel lain tetap. Berikutnya, Iklim Organisasi pada saat peningkatan sebanyak satuan, maka Kepuasan Kerja meningkat sekuantitas 0,988 saat variabel yang lain tetap. Namun, Kepuasan Kerja akan menurun sekuantitas 7,875 (a) apabila Motivasi, Karakteristik Pekerjaan serta Iklim Organisasi adalah nol. 


\section{Koefisien Korelasi serta Koefisien Determinasi}

Koefisien korelasi $(R)$ memaparkan besarnya jalinan antara variabel Motivasi $\left(X_{1}\right)$, Karakteristik Pekerjaan $\left(\mathrm{X}_{2}\right)$, serta Iklim Organisasi $\left(\mathrm{X}_{3}\right)$ dengan variabel Kepuasan Kerja $(\mathrm{Y})$.

\begin{tabular}{|c|c|c|c|c|}
\hline \multicolumn{5}{|c|}{ Model Summary ${ }^{b}$} \\
\hline Model & $\mathrm{R}$ & $\begin{array}{c}\mathrm{R} \\
\text { Square }\end{array}$ & $\begin{array}{c}\text { Adjusted } \\
\text { R } \\
\text { Square }\end{array}$ & $\begin{array}{c}\text { Std. } \\
\text { Error of } \\
\text { the } \\
\text { Estimate }\end{array}$ \\
\hline 1 & ,918 & ,843 & ,825 & 2,765 \\
\hline
\end{tabular}

Penjelasan dalam tabel diatas, nilai koefisien korelasi $(R)$ sekuantitas 0,918 . Nilai $R$ yang tertera berada pada tingkat jalinan yang kuat serta erat. Kemudian, koefisien determinasi $\left(R_{\text {square }}\right)$ dalam variasi variabel $Y$ yakni 0,843 . Nilai $\mathbf{R}_{\text {square }}$ sekuantitas $84,3 \%$ dalam variabel Motivasi, Karakteristik Pekerjaan serta Iklim Organisasi dapat mempengaruhi Kepuasan Kerja, sesertagkan sisanya yaitu 15,7\% dipengaruhi oleh variabel lain yang tidak diteliti dalam eksplorasi ini.

\section{Uji t}

Uji t digunakan untuk mengetahui ada atau tidaknya pengaruh dari variabel bebas secara parsial. Berikut dibawah ini adalah hasil uji t :

Tabel 7 Hasil Uji t

\begin{tabular}{ccc}
\hline Model & $\mathrm{t}$ & Sig. \\
\hline (Constant) & 0,954 & 0,349 \\
\hline $\begin{array}{c}\text { Motivasi } \\
\left(\mathrm{X}_{1}\right)\end{array}$ & 0,164 & 0,871 \\
\hline $\begin{array}{c}\text { Karakteristik } \\
\text { Pekerjaan } \\
\left(\mathrm{X}_{2}\right)\end{array}$ & 2,639 & 0,014 \\
\hline $\begin{array}{c}\text { Iklim } \\
\text { Organisasi } \\
\left(\mathrm{X}_{3}\right)\end{array}$ & 7,777 & 0,000 \\
\hline
\end{tabular}

\section{Uji F}

Uji F bertujuan untuk menguji bagaimana jalinan secara simultan dari variabel bebas mengenai variabel terikat. Berikut adalah hasil uji $\mathrm{F}$ :

Tabel 8 Hasil Uji F

\begin{tabular}{c|c|c}
\hline Model & $F$ & Sig \\
\hline $\begin{array}{c}\text { Regression } \\
\text { Residual } \\
\text { Total }\end{array}$ & 46,460 & $0,000^{\mathrm{b}}$ \\
\hline
\end{tabular}




\section{PEMBAHASAN}

1. Variabel Motivasi secara parsial tidak berdampak mengenai kepuasan kerja. Dikatakan demikian, lantaran hasil dari tsig sekuantitas 0,871 lebih besar dari tingkat signifikansi yakni 0,05. Hasil ini tidak sejalan dengan pendapat dari Busro (2018:51) dimana motivasi menggambarkan hal yang penting lantaran dengan asertaya motivasi yang diberikan maka karyawan merasa puas dalam mengadakanpekerjaannya.

2. Hasil uji t dari variabel Karakteristik Pekerjaan, diperoleh nilai tingkat signifikansi sekuantitas 0,014 dimana nilai tersebut lebih kecil dari signfikansi 0,05. Yang diartikan bahwa Karakteristik Pekerjaan ada pengaruh secara parsial mengenai Kepuasan Kerja. Hasil ini sesuai dengan sependapat dari Gitosudarmo (2001) dalam Lydia Chandra, dkk (2014:313).

3. Hasil pembahasan dari variabel Iklim Organisasi diperoleh nilai tsig sekuantitas 0,000 dimana nilai tersebut lebih kecil dari signifikansi 0,05 sehingga Iklim Organisasi berdampak secara parsial mengenai Kepuasan Kerja karyawan.

4. Pengujian mengenai variabel Kepuasan Kerja (Y), menjelaskan bahwa variabel Motivasi, Karakteristik Pekerjaan serta Iklim Organisasi berdampak secara simultan atau bersama-sama mengenai Kepuasan Kerja. Yang berarti, jika pimpinan menanamkan motivasi yang tinggi kepada karyawan, karakteristik pekerjaan yang disusun sesuai dengan keahlian masing-masing serta iklim organisasi yang tercipta mendukung rasa kenyamanan pada karyawan maka akan mempengaruhi kepuasan dalam diri karyawan.

\section{SIMPULAN}

1. Motivasi tidak berdampak secara signifikan mengenai kepuasan kerja pada karyawan Hotel Ibis Diponegoro. Hal ini lantaran kurangnya pimpinan dalam memberikan serta menanamkan motivasi kepada karyawannya.

2. Secara simultan variabel Motivasi, Karakteristik Pekerjaan serta Iklim Organisasi berdampak mengenai Kepuasan Kerja. Artinya bahwa, apabila pimpinan telah memberikan motivasi serta menanamkan dalam diri karyawan, menyusun pekerjaan sesuai dengan keahlian masing-masing karyawan serta menciptakan suasana kerja yang menyenangkan hal ini akan berdampak karyawan merasa diterima serta di hargai sehingga karyawan merasakan kepuasan dalam bekerja.

\section{IMPLIKASI}

1. Bagi Manajemen hotel, diharapkan dapat memotivasi yang lebih mengenai karyawan sehingga karyawan mampu bekerja lebih baik.

2. Diharapkan bagi peneliti berikutnya, mampu mengembangkan variabel-variabel lain.

\section{KETERBATASAN PENELITIAN}

Penelitian yang dilakukan, masih ada dependensi maupun kekurangan, diantaranya :

1. Dependensi eksplorasi dengan menggunakan kuesioner yaitu jawaban yang diberikan oleh responden tidak menunjukkan keadaan yang sebenarnya.

2. Sedikitnya kuantitas sampel yang diambil lantaran kuantitas populasi kurang dari 100. 


\section{DAFTAR PUSTAKA}

Busro, Muhammad. (2018). Teori-Teori Manajemen Sumber Daya Manusia, Jakarta: Prenada Media.

I Gusti Ayu Yuliana Lestari Putra dan I Nyoman Sudharma. (2016). Pengaruh Iklim Organisasi Dan Stres Kerja Terhadap Kepuasan Kerja Karyawan Pada Hotel Asana Agung Putra Bali, E-Jurnal Manajemen Unud, ISSN:2302-8912, Volume 5, No. 9, hal 5524-5553.

Ismelda Putri dan Suryalena. (2019). Pengaruh Lingkungan Kerja Dan Karakteristik Pekerjaan Terhadap Kepuasan Kerja Karyawan (Studi Kasus Pada Karyawan Hotel Dyan Graha Pekanbaru), JOM FISIP, Volume 6.

Lydia Chandra, Jessica Cindy Mulyanto dan Agustinus Nugroho. (2014). Analisa Pengaruh Karakteristik Pekerjaan Terhadap Kepuasan dan Kinerja Karyawan di Hotel D'Season Surabaya, Jurnal Hospitality dan Manajemen Jasa, Volume 2, No 2, hal 312-325.

Ni Ketut Ayu Juli Astuti dan I Nyoman Sudharma. (2013). Pengaruh Kompensasi Dan Motivasi Terhadap Kepuasan Dan Kinerja Karyawan Pada Hotel Bakung's Beach Cottages Kuta Bali, E-Jurnal Manajemen Unud, E- ISSN: 2302-8912, ISSN: 2302-8912, Volume 2, No. 11, hal 1585-1594.

Oktriwani dan Kasmirudin. (2017). Pengaruh Pengembangan Karir Dan Ikllim Organisasi Terhadap Kepuasan Kerja Karyawan (Studi Kasus Alpha Hotel Pekanbaru), JOM FISIP, Volume 4, No. 2.

Sedarmayanti. (2017). Perencanaan Dan Pengembangan SDM Untuk Meningkatkan Kompetensi, Kinerja, Dan Produktivitas Kerja, Bandung: PT. Refika Aditama.

Sugiyono. (2018). Metode Penelitian Kuantitatif, Kualitatif dan R\&D, Bandung: Alfabeta.

Trihastuti, Aselina Endang. (2019). Komunikasi Internal Organisasi, Yogyakarta: Deepublish.

Wibowo. (2017). Manajemen Kinerja, Depok: PT Raja Grafindo Persada. 